\title{
Optimization of the public procurement system from the standpoint of ensuring economic security
}

\author{
Ksenia Kartavyh*, and Svetlana Chuchkalova \\ Vyatka State University, Moskovskaya str., 36, 610000 Kirov, Russia
}

\begin{abstract}
The article discusses the main amendments to the Federal Law on the Contract System, which planned to be in force in 2021. The changes are aimed at simplifying and optimizing the system of state and municipal procurement. The paper analyzes the goals of improving the contract system. The definition of economic security in the field of public procurement is presented. The degree of influence of amendments to Federal Law No. 44-FZ on the economic security of the procurement system is disclosed.
\end{abstract}

\section{Introduction}

Government purchases are one of the most important parts of the market for goods, works and services, their civilized forms stimulate the economic development of the country, both through the rational use of budgetary funds and through the development of small business through fair competition. The public procurement system is capable of provoking multiplier demand and thus revitalize production. Public procurement plays a major role in supporting Russian producers, and the share of public procurement in final demand is constantly increasing.

It should be noted that the economic nature of the public procurement management mechanism is the redistribution of funds by the state to perform public functions and the formation of a favorable socio-economic situation by directing part of the budget to ensure public demand for goods (works or services).

The effectiveness of public procurement consists of a combination of two factors: the price of the contract and the quality of the products offered for delivery. These factors must play a decisive role in the procurement cycle. The assessment of other factors, such as the country of origin of the goods, does not affect the efficiency of state and municipal procurement, since the main indicator of efficiency in this area is the level of satisfaction of public needs.

For the most effective implementation of public procurement, the state must create conditions for compliance with the basic principles of procurement. The lack of procurement principles in public procurement systems is a sign of corruption in this area.

The public procurement contract system can only achieve maximum efficiency in an open market segment. A significant part of the products that meet the needs of the state are

${ }^{*}$ Corresponding author: kartavyh12@mail.ru 
freely circulated on the market. Therefore, the state has the opportunity to improve the efficiency of the system of state and municipal procurement through competition for the state order.

The state order is one of the most important components of national policy, which affects various sectors of the state's activities: from ensuring national defense to social policy [1].

Thus, the economic security of the contract system in the field of public procurement lies in the targeted, efficient spending of budgetary funds, in achieving the required quality of the products offered for delivery, the maximum possible use of competitive procedures when selecting government contract executors and countering threats of a corruption and criminal nature.

\section{Materials and methods}

At the beginning of 2021, the draft amendments to the federal law of 05.04.2013 were submitted to the State Duma of the Federal Assembly of the Russian Federation. No. 44-FZ "On the contract system in the procurement of goods, works, services to meet state and municipal needs." Federal law draft № 1100997-7 "On amendments to certain legislative acts of the Russian Federation in terms of simplifying and optimizing the procurement procedure for goods, works, services to meet state and municipal needs and invalidating certain provisions of legislative acts of the Russian Federation" (hereinafter - draft law) was prepared in pursuance of the instructions of the President of the Russian Federation and the Government of the Russian Federation on the simplification and optimization of the contract system in the procurement of goods, works, services to meet state and municipal needs [2].

The bill prescribes a comprehensive improvement of the provisions of the Federal Law "On the contract system in the procurement of goods, works, services to meet state and municipal needs" (hereinafter referred to as the Law on the contract system) and pursues specific goals (Table 1).

Table 1. Objectives of the draft Federal Law N 1100997-7.

\begin{tabular}{|c|l|}
\hline № & \multicolumn{1}{c|}{ Objectives of the bill } \\
\hline 1 & Ensuring the effectiveness of the contract system \\
\hline 2 & Ensuring the stability of the contract system \\
\hline 3 & $\begin{array}{l}\text { Ensuring uniformity in the interpretation and application of the provisions of the contract } \\
\text { system }\end{array}$ \\
\hline 4 & Determination of the optimal structure of 44-FZ and the sequence of provisions of 44-FZ \\
\hline 5 & $\begin{array}{l}\text { Unification of requirements for the procedures for determining suppliers (contractors, } \\
\text { performers) }\end{array}$ \\
\hline 6 & $\begin{array}{l}\text { Providing the ability to automate the procedures for determining government contract } \\
\text { executors using various information systems }\end{array}$ \\
\hline 7 & Improving the organization of electronic document management \\
\hline 8 & Raising the level of legal regulation of the system of state and municipal procurement \\
\hline
\end{tabular}

The bill prescribes a reduction the number of competitive procurement methods (Table 2), clarification of their features, definition of new cases of procurement from a single supplier, and adjustment of the procedure for executing a state contract. 
Table 2. Competitive methods for determining the supplier (contractor, executor) prescribed by the bill.

Competitive methods of determining suppliers (contractors, performers)

\begin{tabular}{|l|l|c|}
\hline \multicolumn{1}{|c|}{ COMPETITION } & \multicolumn{1}{|c|}{ AUCTION } & \\
\hline $\begin{array}{l}\text { - closed; } \\
\text { - electronic open } \\
\text { - electronic closed. }\end{array}$ & $\begin{array}{l}\text { - electronic; } \\
\text { - closed; } \\
\text { - electronic closed. }\end{array}$ & REQUEST \\
\hline
\end{tabular}

\section{Results}

Let's consider the main provisions of the bill.

The innovations will affect, in particular, the electronic request for quotations. So, it will be possible to conduct it if the initial (maximum) contract price does not exceed three million rubles. The annual volume of purchases by this method should be no more than $50 \%$ of the total annual volume of purchases of the state customer.

In addition, with the above procurement method, it is necessary to require security deposit for the application if the initial (maximum) contract price exceeds one million rubles. Now this obligation has been established only for tenders and auctions.

It should be noted that the simplification of the contract system in terms of reducing the number of ways to determine the executors of state and municipal orders, as well as a unified and uniform approach to interim procurement measures are aimed not only at optimizing 44-FZ, but also at increasing the economic security of the public procurement system [3].

The bill also provides for universal prequalification of participants. If any competitive procurement is carried out with an initial contract price of twenty million rubles, the customer will require the participant to have a successful experience in executing a contract under Law No. 44-FZ or an agreement under Law No. 223-FZ. Its price must be at least $20 \%$ of the original contract price. The subject of the purchase does not matter. This provision is valid if additional requirement, such as special prequalification, were not applied to the procurement participants.

It is planned to replace bank guarantees with independent guarantees. They can be provided, for example, by regional guarantee organizations. Such organizations or banks must comply with the guarantee obligations, even if they are excluded from the relevant lists. In addition, they will not be released from liability for non-compliance with the terms of the issued guarantees.

These transformations will increase the availability of government orders for small businesses, which in turn will ensure healthy competition in the government procurement market and save budget money.

Let's take a look at the main changes regarding purchase notices:

- $\quad$ the notice will become the main procurement document;

- for procurement by open competitive electronic methods, documentation is not required (documentation is required only for closed competitive procedures);

- all information about the procurement is included in the notice, which is published in the unified information system in the field of procurement; in addition, the list of such information was corrected;

- $\quad$ electronic documents are attached to the notice of procurement;

- deadline for placing a purchase notice will be reduced; 
- $\quad$ it will be possible to change the notice of any procurement with 1 working day before the deadline for submission of applications;

- there will be a general deadline for canceling open and closed e-procurements. This can be done no later than 1 working day before the deadline for submission of applications. Now the term depends on the method.

The simplification of competitive procedures, first of all, will ensure a reduction in the number of errors and violations of legislation by state and municipal customers, therefore, socially significant purchases will be carried out in a timely manner, and the goods necessary for the normal functioning of state institutions will be supplied without interruption.

The requirements for an application for participation in a competitive procurement were unified. We have identified an exhaustive list of information and documents for the application.

Some competitive procurement times will be shortened. For example, an application for participation in an electronic auction is not divided into parts, and it will be considered no later than 2 working days from the day following the deadline for submitting applications.

In addition, the deadline for concluding a contract based on the results of an electronic request for quotations will decrease. The customer will send the contract to the winner within 3 hours from the moment of posting the final protocol. It will take 1 working day to sign it and deposit the security. At the same time, you cannot perform some actions, for example, post a protocol of disagreements.

Reducing the timing of electronic procedures will significantly reduce corruption in the contract system, since the primary reason that customers prefer purchasing from a single supplier is the minimum time limits for concluding a government contract [4].

Also, the bill prescribes increasing in the list of purchases from a single supplier. In particular, regional customers will be able to purchase construction work from a single source by decision of the supreme executive state authority of the constituent entity of the Russian Federation. The annual volume of such purchases should not exceed 3\% of the budget of the constituent entity of the Russian Federation. This procedure can be carried out to prevent emergencies and accidents.

The cases when the contract will need to justify its price were reviewed. The list was supplemented, in particular, with the procurement of teaching services and services of a tour guide (guide) from individuals.

Let's note the main changes concerning the execution of the state and municipal contract:

- when executing a contract based on the results of electronic procedures, most closed electronic procedures, it will be necessary to generate and sign acceptance documents in electronic form, except of some cases. This opportunity has already been implemented in the EIS. While this is a right, not an obligation of the parties;

- it will be possible to adjust some conditions of the contract regardless of whether they are included in the documentation, the contract;

- the procedure for unilateral refusal to execute a contract based on the results of electronic, closed electronic procedures is converted into electronic form. So, the customer only needs to place his solution in the EIS only. It will be sent to the performer within an hour automatically. It is not necessary to inform him about this, for example, by mail. The receiption of the decision by the executor will be appropriate notification;

- the contractor will have 3 days to appeal the decision on unilateral refusal to the supervisory authority. The effective date for such decision has been increased from 10 calendar days up to 15 .

The advantages of electronic document management are presented in Table 3. 
Table 3. Advantages of electronic document management in the contract system.

\begin{tabular}{|l|l|}
\hline \multicolumn{2}{|c|}{ Advantages of electronic document management (EDM) in the contract system } \\
\hline \multicolumn{1}{|c|}{ for executors of the state order } & \multicolumn{1}{c|}{ for government customers } \\
\hline $\begin{array}{l}\text { 1. EDM allows you to reduce the } \\
\text { time for preparation and delivery of } \\
\text { documents. }\end{array}$ & $\begin{array}{l}\text { 1. EDM simplifies the process of document } \\
\text { circulation during the procurement. } \\
\text { 2. EDM speeds up the process of going } \\
\text { 2. EDM provides an opportunity to } \\
\text { avoid paperwork. }\end{array}$ \\
$\begin{array}{l}\text { 3. EDM reduces the likelihood of } \\
\text { errors when filling out forms. }\end{array}$ & $\begin{array}{l}\text { 3. EDM ensures the identity of information } \\
\text { in documents that are formed at different } \\
\text { stages of the same procedure. }\end{array}$ \\
$\begin{array}{l}\text { 4. EDM allows you to visually see } \\
\text { the process of passing the check. }\end{array}$ & $\begin{array}{l}\text { 4. EDM reduces the likelihood of errors due } \\
\text { to autocomplete and verification system. }\end{array}$ \\
$\begin{array}{l}\text { 5. EDM allows you to speed up the } \\
\text { payment process under the contract. }\end{array}$ & $\begin{array}{l}\text { 5. EDM provides clarity of the procurement } \\
\text { procedure for counterparties, which reduces } \\
\text { the number of disputes and complaints about } \\
\text { the customer's actions. }\end{array}$ \\
& $\begin{array}{l}\text { 6. EDM allows you to get correct data for } \\
\text { reporting. }\end{array}$ \\
\hline
\end{tabular}

\section{Discussion}

Let's indicate the main significant changes prescribed by the draft law No. 1100997-7:

- reducing the number of competitive methods for determining a supplier (contractor, executor) to the three most common and used by customers (competition, auction, request for quotations);

- $\quad$ obtaining by the customer the opportunity to discuss the proposed procurement object and its description with potential procurement participants at the procurement planning stage (before placing a notice of the procurement);

- establishing a list of cases for conducting "urgent" purchases by making requests for quotations without restrictions on the volume and price of the contract, applying the universal requirements of the legislation;

- reduction of requirements for notifications and documents on purchases, applications for participation in purchases carried out in various ways, requirements for the customer's choice of a method for determining a supplier (contractor, executor);

- reduction of the time required for the implementation of procedures (including consideration of applications, parts of applications) when carrying out various methods of determining suppliers (contractors, performers)

- $\quad$ exception of the need for a mandatory extension of the deadline for submission of applications, as well as an additional procedure in the absence of applications for participation in the procurement;

- $\quad$ clarification of purchase cases from a single supplier (contractor, performer);

- simplification of the requirements for creation and implementation of the activities procedures of the customer's commission for procurement.

Thus, if the draft law is adopted, the legislation on the contract system will undergo a number of global changes, which will be aimed at facilitating the procurement activities of customers. 
It is planned that the amendments will enter into force by stages. Transitional provisions are also assumed. The first innovations have been entered in force since April 01, 2021.

Experts note that among the novels introduced by the bill there are both unequivocally positive and controversial changes. So, the use of electronic document management at all stages of both the bidding procedure itself and the further execution of the contract, they call an obviously positive innovation - this will allow to avoid regular disputes between customers and suppliers in terms of notifications, receipt of claims, acts and other documentation. Experts assign universal prequalification to more controversial initiatives, which will affect both participation in procurement and appeal of procurement procedures. This will clearly increase the value of the legal entity, since the participants will value an organization with experience in executing government contracts. It can also have a positive impact on attitudes towards the goals of maintaining a registry of unscrupulous suppliers. As a result, market participants will have a more responsible approach to participation in procurement and fulfillment of contractual obligations, since the risk of "losing" the company will have more serious consequences. At the same time, this innovation does not take into account the interests of enterprises that have been conducting core activities for many years, but are participating in procurement procedures for the first time. Therefore, the innovation caused an ambiguous reaction. In addition, the innovation limits the circle of persons who have the right to appeal the results of the procurement procedure. This can only be done by those persons who can potentially be participants in a particular procurement. Such a right will also be determined with the help of the institute of universal prequalification. This is a peculiar method of dealing with so-called professional complainants. As a result, the burden on the antimonopoly authorities and the risks of unjustified suspension and appeal of purchases will decrease.

\section{Conclusions}

Thus, the proposed in the draft federal law No. 1100997-7 "On Amending Certain Legislative Acts of the Russian Federation in terms of simplifying and optimizing the procedure for the procurement of goods, works, services to meet state and municipal needs and invalidating certain provisions of legislative acts of the Russian Federation "public procurement system management tools will increase awareness and trust among procurement participants, optimize control in public procurement, prevent corruption, as well as obtain significant savings in state budgetary funds by optimizing the procurement contract system.

\section{References}

1. E. Karanina, O. Ryazanova, A. Timin, EMMFT, 692 (2017)

2. Legal system Consultant plus, http://www.consultant.ru

3. L. Domracheva, E. Karanina, A. Bakhtimov, M. Kochetkov, MATEC Web of Conferences, 193, 05067 (2018)

4. E. Karanina, O. Ryazanova, N. Gritsuk, MATEC Web of Conferences, 193, 01031 (2018)

5. E. Karanina, K. Kartavyh, MATEC Web of Conferences, 170, 01003 (2018)

6. T. Marinchenko, Journal of VNIIMZH, 2, 204 (2019)

7. S. N. Shirokov, T. I. Pisarenko, T. P. Kutuzova, ISPSAU, 3, 168 (2017)

8. E. Karanina, E. Sapozhnikova, D. Loginov, A. Holkin, E. Sergievskaya, A. Zurakhovskii, MATEC Web of Conferences, 106 (2018) 